\title{
Are We Approaching the End of the Linear No-Threshold Era?
}

\author{
Mohan Doss
}

Diagnostic Imaging, Fox Chase Cancer Center, Philadelphia, Pennsylvania

The linear no-threshold (LNT) model for radiation-induced cancer was adopted by national and international advisory bodies in the 1950s and has guided radiation protection policies worldwide since then. The resulting strict regulations have increased the compliance costs for the various uses of radiation, including nuclear medicine. The concerns about low levels of radiation due to the absence of a threshold have also resulted in adverse consequences. Justification of the LNT model was based on the concept that low levels of radiation increase mutations and that increased mutations imply increased cancers. This concept may not be valid. Low-dose radiation boosts defenses such as antioxidants and DNA repair enzymes. The boosted defenses would reduce the endogenous DNA damage that would have occurred in the subsequent period, and so the result would be reduced DNA damage and mutations. Whereas mutations are necessary for causing cancer, they are not sufficient since the immune system eliminates cancer cells or keeps them under control. The immune system plays an extremely important role in preventing cancer, as indicated by the substantially increased cancer risk in immune-suppressed patients. Hence, since low-dose radiation enhances the immune system, it would reduce cancers, resulting in a phenomenon known as radiation hormesis. There is considerable evidence for radiation hormesis and against the LNT model, including studies of atomic bomb survivors, background radiation, environmental radiation, cancer patients, medical radiation, and occupational exposures. Though Commentary 27 published by the National Council on Radiation Protection and Measurements concluded that recent epidemiologic studies broadly support the LNT model, a critical examination of the studies has shown that they do not. Another deficiency of Commentary 27 is that it did not consider the vast available evidence for radiation hormesis. Other advisory body reports that have supported the LNT model have similar deficiencies. Advisory bodies are urged to critically evaluate the evidence supporting both sides and arrive at an objective conclusion on the validity of the LNT model. Considering the strength of the evidence against the LNT model and the weakness of the evidence for it, the present analysis indicates that advisory bodies would be compelled to reject the LNT model. Hence, we may be approaching the end of the LNT model era.

Key Words: LNT model; radiation hormesis; NCRP commentary no. 27; BEIR VII report

J Nucl Med 2018; 59:1786-1793

DOI: 10.2967/jnumed.118.217182

Received Sep. 7, 2018; revision accepted Sep. 24, 2018.

For correspondence or reprints contact: Mohan Doss, Diagnostic Imaging,

Fox Chase Cancer Center, 333 Cottman Ave., Philadelphia, PA 19111.

E-mail: mohan.doss@fccc.edu

Published online Sep. 27, 2018.

COPYRIGHT (C 2018 by the Society of Nuclear Medicine and Molecular Imaging.
$\mathbf{T}$ he cancer risk attributable to radiation is known to increase linearly with radiation dose for high levels of radiation, as observed, for example, in a study of the atomic bomb survivors (1). However, there has long been disagreement in the scientific community about the carcinogenicity of low levels of radiation (2). The prevailing view, supported almost unanimously by national and international advisory bodies since the 1950s, is the linear nothreshold (LNT) model for radiation-induced cancers (3). Justification of the LNT model was based on the concept that even a small amount of radiation increases DNA damage and mutations and that increased mutations imply increased cancers (4). The atomic bomb survivor data, which are generally regarded as the most important for estimating the health effects of radiation, were consistent with the LNT model until recently (1) and were used to justify the continuing use of the LNT model by advisory bodies (5).

A contradictory point of view on the health effects of low-dose radiation is that it has benefits. This concept, known as radiation hormesis, was proposed by Luckey in 1980 (6). Justification of radiation hormesis is based on the concept that low radiation doses stimulate bodily defenses, resulting in beneficial health effects including reduction of cancers (7). However, most advisory bodies have not accepted this view and continue to support the LNT model (5).

The LNT model and the consequent concerns about the smallest amounts of radiation have resulted in strict radiation safety regulations that have increased the compliance costs for all uses of radiation, including nuclear medicine. The concerns about low radiation doses have also resulted in adverse consequences in many areas, including diagnostic imaging $(8-10)$. Hence, it is important that we periodically evaluate the validity of the LNT model.

Whereas many studies have supported the LNT model over the years, others have supported radiation hormesis, and the controversy over low-dose radiation carcinogenicity remains unresolved. In fact, in contemporaneous reports, 2 advisory bodies took opposite stances on the LNT model, with Biologic Effects of Ionizing Radiation report VII (BEIR VII) by the National Academies of Sciences (5) supporting its use and a report by the French Academy of Sciences (11) opposing it.

BEIR VII concluded that the LNT model is consistent with available evidence, quoting the cancer data from the atomic bomb survivors (1) and a 15-country study of radiation workers (12). However, the shape of the dose-response curve in a subsequent update to the cancer mortality data for the atomic bomb survivors (13) was inconsistent with the LNT model because of the significant curvature in the 0 - to $2-G y$ dose range. When a correction 
was applied for the likely negative bias in the baseline cancer rates used in processing the data, these data become consistent with radiation hormesis (14). In addition, because of a reanalysis of the Canadian data, the 15-country study of radiation workers no longer shows significantly increased cancer risk in the irradiated workers (15). Hence, the main studies quoted by BEIR VII to support the LNT model do not support it any longer.

Since the time of BEIR VII, several studies have supported the LNT model $(16,17)$. However, major deficiencies have been identified in such studies, making their conclusions not credible $(9,18,19)$. On the other hand, several studies have supported radiation hormesis $(20,21)$, and such studies have not been refuted. Thus, a resolution of the controversy over low-dose radiation carcinogenicity appears to be imminent. In view of this situation, it was surprising that the National Council on Radiation Protection and Measurements (NCRP), in its Commentary 27, reviewing 29 epidemiologic studies, concluded that it supports the continued use of the LNT model (22). In this article, I will review the current state of knowledge in this field and discuss whether the NCRP is justified in its conclusion.

\section{CURRENT STATE OF KNOWLEDGE ON THE CAUSE OF CANCER AND THE CARCINOGENICITY OF LOW-DOSE RADIATION}

It is now widely accepted that cancer is the result of the gradual accumulation of driver gene mutations that successively increase cell proliferation (23). However, such mutations may not be sufficient to cause cancer. For example, though mutations accumulate at the highest rates in the spleen from conception to maturity, there is no increase in lymphomas during that period, as observed in a mouse study (24). For humans also, cancers occur at the lowest rates at a young age (25), when mutations would be accumulating at the highest rates. Mutations are necessary but may not be sufficient to cause clinical cancer, since the immune system would eliminate or control cancer cells, resulting in covert cancers (26). A recent analysis has concluded that clonal expansion of cancerassociated mutations is an extremely common, if not universal, condition in somatic tissues (27). It has been estimated that almost everyone develops covert cancers, but only a small percentage of those who have covert cancer develop clinical cancer (28). When the immune system is suppressed, such as in organ-transplant patients or AIDS patients, cancer risk increases substantially (29). In young organ-transplant patients, the cancer mortality rate is increased by a factor of about 60 (30), and in young AIDS patients, cancer incidence is increased by a factor of about 40 (31). Such large increases in cancer rates when the immune system is suppressed indicate that the immune system plays a major role in preventing covert cancers from developing into clinical cancers.

Now let us examine the current state of knowledge on the health effects of low-dose radiation. It is well known that exposure to low levels of radiation results in increased DNA damage (32). However, even in the absence of radiation, DNA damage does occur from endogenous causes and is much more than the damage caused by low levels of radiation (33). Low-dose radiation also boosts defenses such as antioxidants and DNA repair enzymes (7). With the boosted defenses, there would be less endogenous DNA damage and mutations in the subsequent period, and the ultimate result would be reduced DNA damage and mutations $(9,33)$. This result has been observed in studies of fruit flies (34) and mice (35). In addition, low-dose radiation enhances the immune system (36).
Considering the important role played by the immune system in preventing cancers, the boosted immune system would reduce cancers. Evidence against the LNT model or for radiation hormesis has been observed in a variety of human studies. The graphs in Figures 1-3 illustrate some of this evidence in chronologic order of publication date to highlight the availability of the evidence over several decades. The evidence includes studies of atomic bomb survivors (Figs. 1A and 3C) (14,37), background radiation (Fig. 2B) (38), cancer patients (Figs. 1C and 2C) (39,40), environmental radiation (Figs. 2A and 3D ) (19,41), medical radiation (Figs. 1D and 3B) $(20,42)$, and occupational exposure (Figs. 1B, 2D, and 3A) $(21,43,44)$.

Notwithstanding the above state of knowledge in this field, NCRP Commentary 27 (22) concluded that recent epidemiologic studies support the continued use of the LNT model.

\section{DISCUSSION OF NCRP COMMENTARY 27}

NCRP Commentary 27 stated that some studies provided strong support for the LNT model, some provided weak or moderate support, and others provided no support or were inconclusive. The conclusion was that the data are broadly supportive of the LNT model. I will now discuss in some detail the 5 studies that the NCRP claimed provided strong support for the LNT model.

The first is the study of solid cancer incidence among atomic bomb survivors (45). The abstract of this publication states: "uncertainties in the shape of the dose response preclude definitive conclusions to confidently guide radiation protection policies." With such an indeterminate conclusion by the authors, this study should not be considered supportive of the LNT model.

One problem with the atomic bomb survivor data, as traditionally reported, is the shape of the dose-response function that the data analysis used to extract excess relative risks (ERRs). Since low radiation doses have resulted in decreased cancers in many studies (Figs. 1-3), and since high radiation doses would increase cancer risk (1), a J-shaped dose-response function should have been used while processing the data. However, an LNT doseresponse function was used in analyzing the data, and so the resultant ERRs may not be reliable and should not be used to draw conclusions on the dose-response relationship for radiation. Notwithstanding this reasoning, if these ERRs are used, the ERRs as a function of radiation dose show a linear increase for low doses near zero. However, the dose-response function also shows a significant curvature for the dose range of 0-2 Gy, and the significant curvature would be inconsistent with the LNT model because it would imply that cancer risk decreases or remains unchanged as radiation dose increases. For the above reasons, this study does not support the LNT model.

The second study is the International Nuclear Workers (INWORKS) study of nuclear industry workers in France, the United Kingdom, and the United States during 1945-2005 (46). The relative rate for solid cancer mortality in the workers was reported to be consistent with a linear dose-response shape (Fig. 4), with ERR/Gy being 0.48 (90\% confidence interval [CI], 0.20-0.79). Smoking prevalence declined considerably between the 1940s and 2000s in these countries $(47,48)$. Since smoking increases all cancer risk $(49)$, and the highest occupational radiation doses were in the earlier years (50), considerable confounding of the cancer mortality dose-response data due to smoking is likely. For French nuclear workers, a study reported that lung cancer rate is substantially confounded by smoking (51). The INWORKS study stated that contrary to the pattern that 


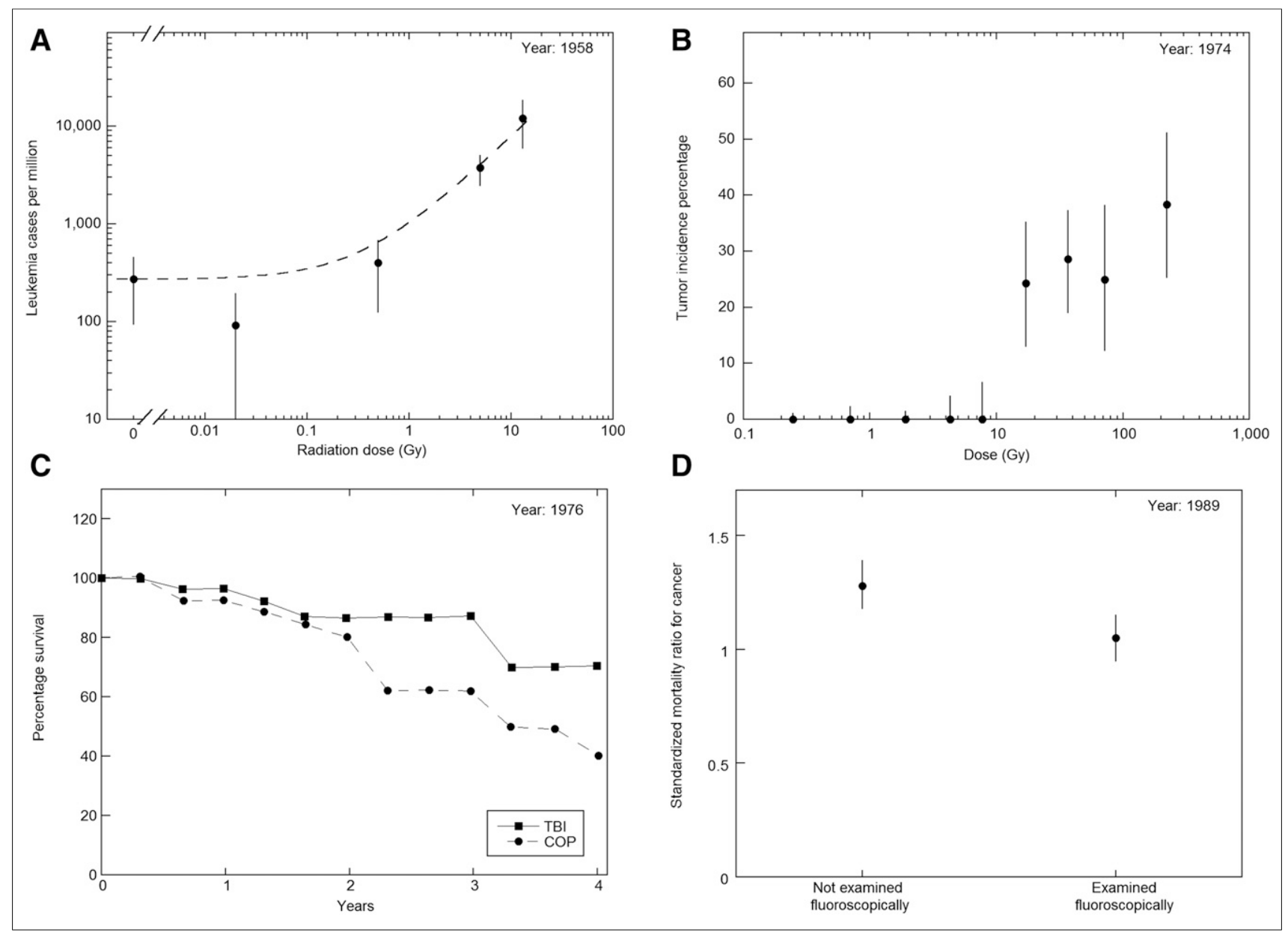

FIGURE 1. Evidence against LNT model or for radiation hormesis from 1950s to 1980s. (A) Leukemia in Hiroshima survivors as function of radiation dose, using data from Table 7, Annex F, of UNSCEAR report (37). Dashed line is LNT model fit to high-dose data. Data show reduction in leukemia at low doses with threshold dose exceeding $\sim 0.5$ Gy. Error bars are $95 \%$ Cls. (B) Bone sarcomas in radium dial painters (44). Error bars are SDs. No bone sarcomas were observed for doses below $\sim 10 \mathrm{~Gy}$. (C) Survival of lymphosarcoma patients treated with low-dose total-body irradiation (TBI) (10 cGy 15 times in $5 \mathrm{wk}$ ) vs. cyclophosphamide, vincristine, and prednisone (COP) (39). Survival curves do not significantly differ. TBI had cancer therapeutic effect equivalent to chemotherapy. (D) SMRs for all cancers in Massachusetts tuberculosis patients who underwent repeated fluoroscopy vs. those who did not (42). Error bars are $95 \%$ Cls. Patients undergoing fluoroscopy had lower all-cancer risk. (Note: threshold dose in A and B is inconsistent with LNT model. Cancer preventive or therapeutic effect observed in C and D after exposure to low levels of radiation contradicts LNT model and is consistent with radiation hormesis).

would be expected if there was confounding by smoking, the magnitude of the estimated ERR/Gy for solid cancers was essentially unchanged after excluding lung cancer. However, the use of such negative control outcomes to detect confounding also requires the assumption that the exposure of interest does not cause the negative control outcome (51). There is evidence that low-dose radiation prevents lung cancer in animal studies (52). Also, reduction of lung cancers has been reported in tuberculosis patients who underwent fluoroscopy, in comparison to patients not undergoing fluoroscopy (42). Therefore, the use of a negative control to exclude confounding by smoking in the INWORKS study may not be appropriate. The INWORKS study stated that when all smoking-related cancers were excluded, the ERR/Gy for solid cancers was $0.37(90 \%$ CI, -0.14 to 0.95 ), which is consistent with no increased cancer risk in the irradiated workers. Hence, the INWORKS study does not support the LNT model.

The third is the study of breast cancer risk in Massachusetts tuberculosis patients who underwent repeated fluoroscopic examinations
(53). In this study, the bin size used for radiation dose in the underlying data (54) was large, covering the range of 1-99 cGy, and so included both low and high doses, likely masking any hormetic reduction of breast cancer at low doses. A Canadian study of tuberculosis patients who underwent repeated fluoroscopy (55) used a smaller bin size and did observe a reduction in the breast cancer mortality rate for low doses, but a later study (56) with a larger bin size masked the hormetic reduction. Another problem with the Massachusetts study (53) is that it examined breast cancer only. An earlier study on the same cohort (42) stated that for female fluoroscopy patients, standardized mortality ratios (SMRs) for breast cancer were significantly increased, at 1.4 (95\% CI, 1.051.75), but SMRs for all cancers were not significantly increased, at 1.1 (95\% CI, 0.95-1.24), indicating that other cancers had decreased, with no overall increase in cancer mortality. For male and female tuberculosis patients not undergoing fluoroscopy, SMRs for all cancers were significantly elevated, at 1.28 (95\% CI, 1.181.38), whereas for the patients who underwent fluoroscopy, SMRs 

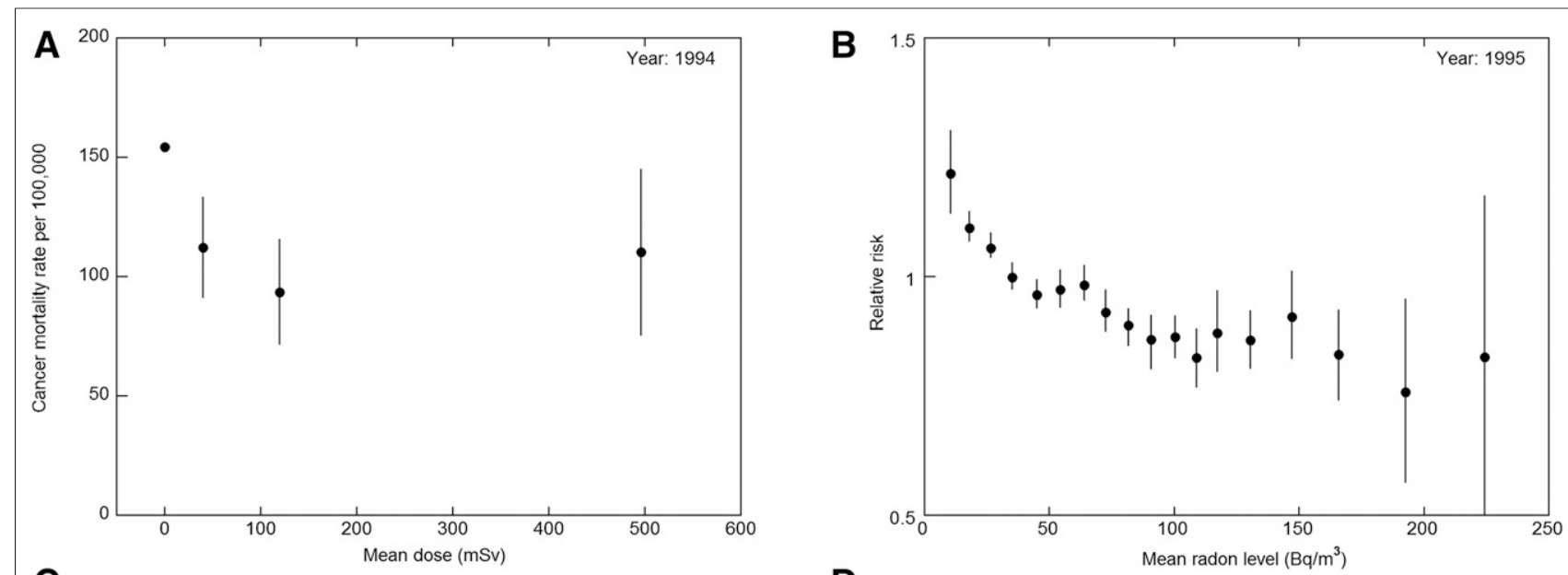

C

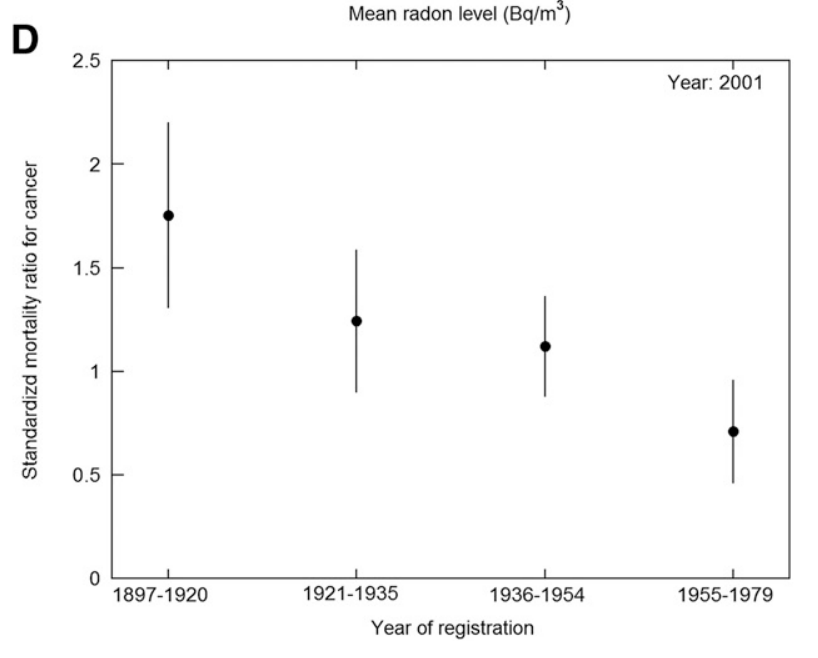

FIGURE 2. Evidence against LNT model or for radiation hormesis from 1990 s to 2000 s. Error bars are $95 \%$ Cls. (A) Cancer mortality rates in residents of evacuated villages near Mayak nuclear weapons facility after accident that released radioactivity into environment, as function of radiation dose (41). Data point at zero dose is from control population. (B) Relative risk for lung cancer mortality of males in counties of United States as function of residential radon levels, corrected for smoking (38). (C) Survival of non-Hodgkin lymphoma patients having radiation therapy (RT) to tumor compared with patients having interspersed low-dose total-body or half-body irradiation (TBI or HBI) between radiation treatments to tumor (40). TBI/HBI had cancer therapeutic effect. (D) SMR for cancer mortality in male British radiologists compared with male physicians, for different periods of registration (43). Radiologists who registered during 1955-1979 had exposure to low levels of radiation and were observed to have reduced cancer rates compared with male physicians, consistent with radiation hormesis. (Note: All these data show reduction of cancers after low radiation exposures, contradicting LNT model and consistent with radiation hormesis).

for all cancers showed no increase, at 1.05 (95\% CI, 0.95-1.15), indicating a reduction in the all-cancer mortality rate after the fluoroscopy. Radiation hormesis can explain the decrease in all cancers in this cohort. Though the breast received high radiation doses from the fluoroscopic examinations, other parts of the body would have received lower doses resulting in the reduction of other cancers and all cancers. Examining only breast cancer risk would misrepresent the overall health effect of the irradiation by ignoring the reduction of other and all cancers. Therefore, the Massachusetts study does not provide evidence for the LNT model.

The fourth one is the study of solid cancer incidence in the atomic bomb survivors exposed in utero or in childhood (57). As discussed earlier, the use of an LNT dose-response shape while extracting ERRs is not justified because of the large observed evidence for radiation hormesis (Figs. 1-3). Therefore, the extracted ERRs would not be reliable for determining the dose-response relationship. Notwithstanding this reasoning, if we use the ERRs as reported, the dose-response shape in this study also shows significant curvature $(P=0.09)$ for the dose range of $0-2 \mathrm{~Gy}$, and significant curvature would be inconsistent with the LNT model, as discussed earlier.

The fifth study is the pooled analysis of thyroid cancer incidence after childhood radiation exposures (58). One issue with this study is that thyroid cancer incidence is subject to considerable overdiagnosis. A sign of such overdiagnosis is that despite the large increase in thyroid cancer incidence due to increased imaging and screening over the past few decades, there has been little change in thyroid cancer mortality rates in the United States and South Korea $(59,60)$. A recent review has concluded that most thyroid cancers are self-limiting and do not metastasize and, so, has recommended against screening for thyroid cancer (61). Hence, the pooled analysis of thyroid cancer incidence would also likely be subject to large overdiagnosis, and conclusions based on such studies would not provide useful information on the shape of the dose-response curve. Therefore, this study also does not support the LNT model. 

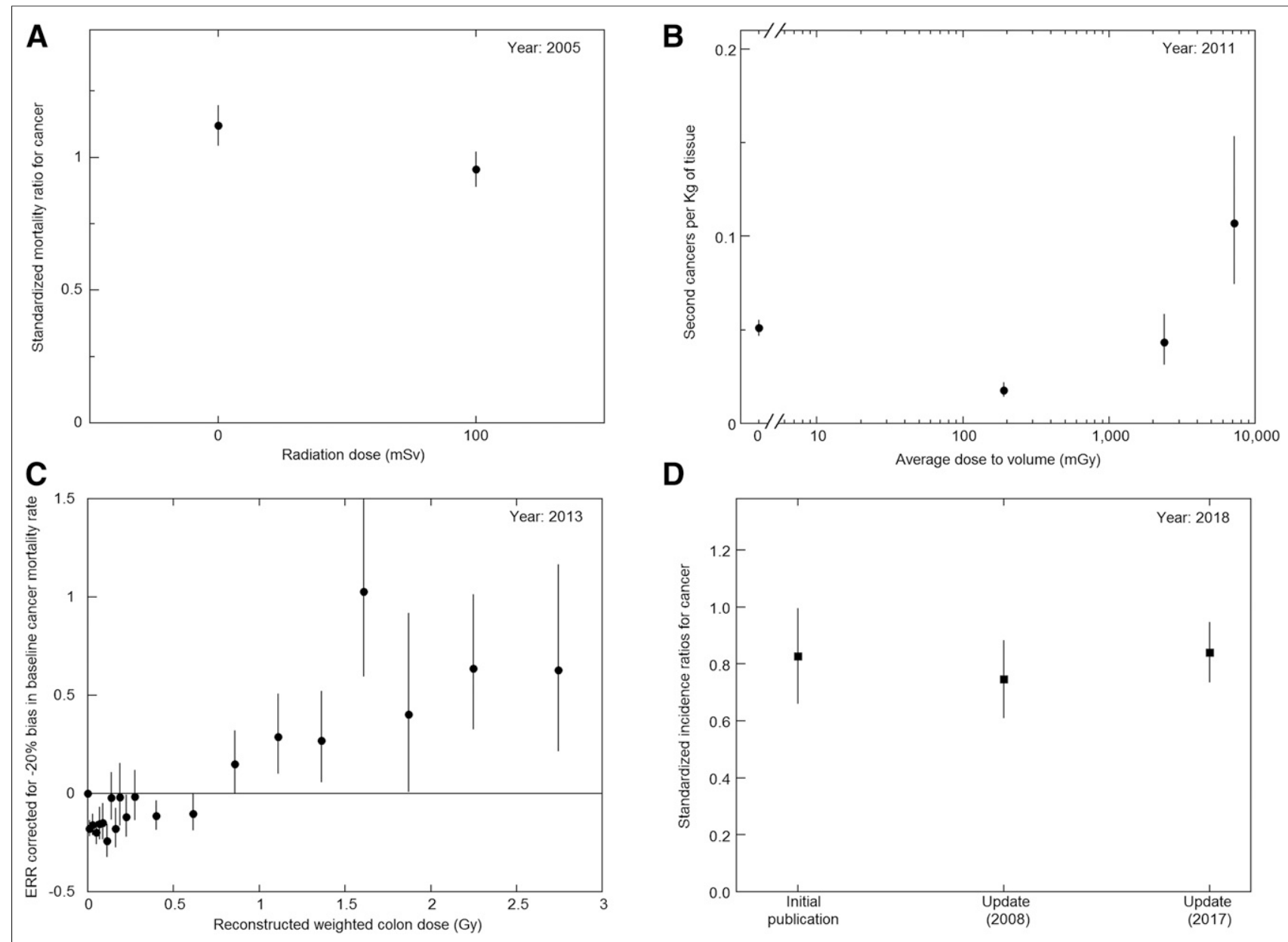

FIGURE 3. Evidence against LNT model or for radiation hormesis from 2000 s to 2010s. (A) SMRs for all cancers in nuclear shipyard workers as function of radiation dose (21). Error bars are $95 \%$ Cls. (B) Second cancers per kilogram of tissue in radiation therapy patients as function of dose to tissue (20). Error bars are SDs. (C) ERR for solid cancer mortality in atomic bomb survivors, corrected for likely negative bias in baseline cancer mortality rate used in analyzing data (14). Error bars are 95\% Cls. (D) Standardized incidence ratios for cancers in irradiated residents of radiocontaminated apartment buildings in Taiwan, from initial study and 2 updates (19). Error bars are 95\% Cls. (Note: All studies show reduction of cancers after low radiation exposures, contradicting LNT model and consistent with radiation hormesis).

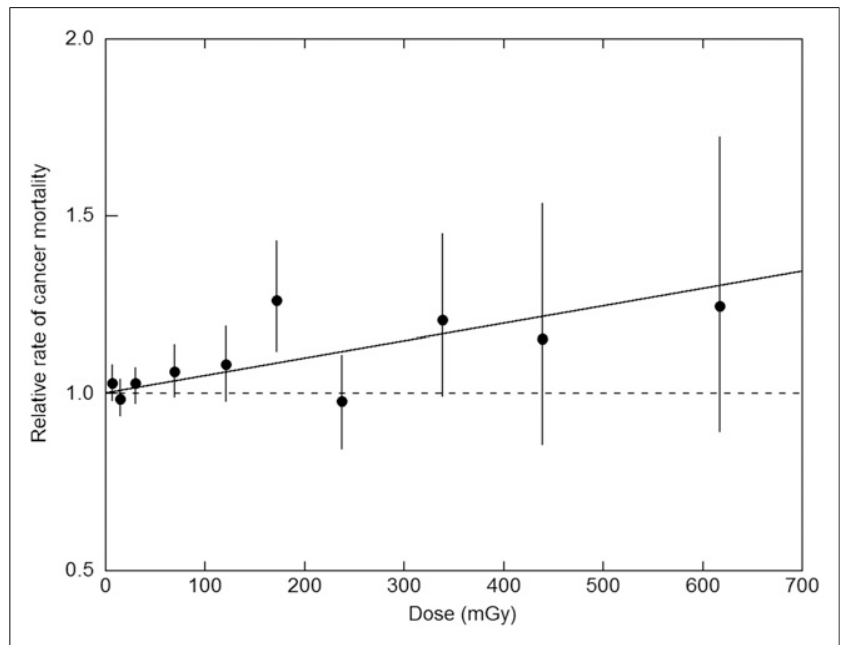

FIGURE 4. Relative risk of cancer mortality as function of radiation dose in nuclear industry workers from INWORKS study (46). Error bars indicate $95 \%$ Cls. Solid line is linear model fit to data.
The above discussion shows that none of the studies claimed by the NCRP to strongly support the LNT model actually do support the model, nor do the studies claimed to provide moderate support or weak-to-moderate support (Table 1). Therefore, the conclusion of NCRP Commentary 27 that recent epidemiologic studies broadly support the LNT model may not be justifiable.

\section{CONCLUSION}

For some issues such as the carcinogenicity of low levels of radiation, a substantial number of publications may reach opposite conclusions, making the issues controversial. It is clear that two studies reaching opposing conclusions cannot both be correct and that the study reaching the wrong conclusion would likely have major shortcomings. Therefore, when advisory bodies consider such controversial issues, they should critically examine the studies supporting both sides so that they can identify the studies with major shortcomings and discard them. This procedure would allow an objective conclusion to be reached. Hence, a major deficiency of NCRP Commentary 27 is that it did not consider the 
TABLE 1

Comments on Epidemiologic Studies that NCRP Commentary 27 Claimed to Provide Moderate, or Weak-to-Moderate, Support for LNT Model

\begin{tabular}{|c|c|}
\hline Study & Comments \\
\hline Mayak nuclear workers (62) & $\begin{array}{l}\text { For radiation doses less than } 0.5 \text { Gy, ERR is consistent with no increased cancer risk (Fig. } 2 \\
\text { of the publication). }\end{array}$ \\
\hline $\begin{array}{l}\text { Chernobyl fallout, Ukraine and } \\
\text { Belarus thyroid cancer }(63)\end{array}$ & $\begin{array}{l}\text { Like Massachusetts tuberculosis study (53), this study has flaw of considering thyroid } \\
\text { cancer incidence, which is subject to large overdiagnosis, and considering thyroid cancer } \\
\text { only. }\end{array}$ \\
\hline $\begin{array}{l}\text { Breast cancer studies, after } \\
\text { childhood exposure (64) }\end{array}$ & $\begin{array}{l}\text { According to the publication, } 3 \% \text { of women in whole cohort had breast doses exceeding } 1 \\
\text { Gy, and mean dose was } 0.18 \text { Gy. Thus, cohort included patients with highly carcinogenic } \\
\text { doses, even though average dose was much lower. Increased cancers would occur in } \\
\text { patients with high breast doses and should not be attributed to low radiation doses. } \\
\text { Dose-response data from earlier publication on same cohort (65) show no significantly } \\
\text { increased breast cancer risk for breast doses less than } 1 \text { Gy (Table } 3 \text { of the publication). }\end{array}$ \\
\hline $\begin{array}{l}\text { In utero exposure, Japan atomic } \\
\text { bombs }(57)\end{array}$ & $\begin{array}{l}\text { Data shown in Table } 4 \text { of the publication indicate no significant increase in relative risk of } \\
\text { cancer for low-dose category }(0.005-0.2 \mathrm{~Sv}) \text { for in utero or childhood exposure. Next } \\
\text { dose range }(>0.2 \mathrm{~Sv}) \text { shows significantly increased relative risk for a few categories. } \\
\text { Because this dose range includes high doses, increased relative risk for this dose range } \\
\text { may not be attributable to low radiation doses. A review of a large number of studies } \\
(57,66) \text { indicated that no definitive conclusion can be drawn on carcinogenic effect of in } \\
\text { utero exposure. }\end{array}$ \\
\hline Techa River, nearby residents (67) & $\begin{array}{l}\text { Data in Table } 3 \text { of the publication indicate no significant increase in cancer risk for any dose } \\
\text { range. }\end{array}$ \\
\hline In utero exposure, medical (68) & $\begin{array}{l}\text { This is a review article. A later review of a large number of studies }(66) \text { indicated that no } \\
\text { definitive conclusion can be drawn on carcinogenic effect of in utero exposure. }\end{array}$ \\
\hline Japan nuclear workers (69) & $\begin{array}{l}\text { The publication stated that data are likely confounded by alcohol drinking. Data in Table } 2 \text { of } \\
\text { the publication indicate that this study does not show significantly increased cancer risk } \\
\text { in radiation workers when alcohol-related cancers are excluded. }\end{array}$ \\
\hline $\begin{array}{l}\text { Chernobyl cleanup workers, } \\
\text { Russia (70) }\end{array}$ & $\begin{array}{l}\text { SMR for all cancers is } 0.95(95 \% \mathrm{Cl}, 0.92-0.99) \text { (from Fig. } 5 \text { of the publication), indicating } \\
\text { reduction of cancer in this cohort after radiation exposure. }\end{array}$ \\
\hline $\begin{array}{l}\text { U.S. radiologic technologists } \\
(71,72)\end{array}$ & $\begin{array}{l}\text { Overall cancer mortality rate for radiologic technologists was significantly lower, with SMR } \\
\text { of } 0.82(95 \% \mathrm{Cl}, 0.80-0.84) \text {, as reported in Table A2 of supplementary materials of one } \\
\text { publication (71). The other publication (72) studied breast cancer only. Studying single } \\
\text { type of cancer does not provide complete information on carcinogenic effect of low } \\
\text { radiation doses, as hormetic reductions of other cancers would not be considered. }\end{array}$ \\
\hline Mound nuclear workers (73) & $\begin{array}{l}\text { Overall cancer mortality rate was significantly lower in radiation workers, with SMR of } 0.86 \\
(95 \% \mathrm{Cl}, 0.79-0.93) \text {. }\end{array}$ \\
\hline Rocketdyne nuclear workers (74) & $\begin{array}{l}\text { Overall cancer mortality rate was significantly lower in radiation workers, with SMR of } 0.88 \\
(95 \% \mathrm{Cl}, 0.81-0.94) \text {, and relative risk for all cancer mortality did not significantly increase. }\end{array}$ \\
\hline $\begin{array}{l}\text { French uranium processing } \\
\text { workers }(75)\end{array}$ & $\begin{array}{l}\text { Overall cancer mortality rate was significantly lower in radiation workers, with SMR of } 0.79 \\
(95 \% \mathrm{Cl}, 0.72-0.87) \text {. }\end{array}$ \\
\hline Medical x-ray workers, China (76) & $\begin{array}{l}\text { Data below } 0.15 \text { Gy are consistent with no increase in cancer risk (Fig. } 2 \text { of the publication). } \\
\text { Shape of dose-response curve cannot be determined reliably from these data because of } \\
\text { large errors. }\end{array}$ \\
\hline $\begin{array}{c}\text { Taiwan radiocontaminated } \\
\text { buildings, residents (17) }\end{array}$ & $\begin{array}{l}\text { As explained in the publication (19), Standardized incidence ratios for all cancers, calculated } \\
\text { using data in the publication, are significantly reduced in irradiated residents of } \\
\text { radiocontaminated buildings. }\end{array}$ \\
\hline $\begin{array}{l}\text { Background radiation levels and } \\
\text { childhood leukemia ( } 77)\end{array}$ & $\begin{array}{l}\text { Breastfeeding and child-care attendance are known to be important factors in childhood } \\
\text { leukemia }(78,79) \text { but were not considered confounding factors in the study. Because } \\
\text { relative risk per millisievert for leukemia was } 1.07 \text { ( } 95 \% \mathrm{Cl}, 1.01-1.13) \text {, small changes in } \\
\text { these confounding factors could make increase in risk not significant. We should await } \\
\text { better studies that account for such major confounding factors. }\end{array}$ \\
\hline
\end{tabular}


studies that supported radiation hormesis. If the NCRP had considered such studies and had critically evaluated publications supporting both sides, it would not have reached its present conclusion. Previous advisory body reports that have supported the LNT model, such as BEIR VII, have the same deficiency of not considering publications that support radiation hormesis and not critically examining the publications. Hence, notwithstanding the almost unanimous support of the advisory bodies for the LNT model, their recommendations are questionable. The advisory bodies are urged to critically evaluate the available evidence on both sides to draw an objective conclusion. Considering the strength of the evidence against the LNT model (Figs. 1-3) and the weakness of the evidence for it (Fig. 4), the present analysis indicates advisory bodies would be compelled to reject the LNT model. Hence, we may be approaching the end of the LNT model era.

\section{DISCLOSURE}

No potential conflict of interest relevant to this article was reported.

\section{REFERENCES}

1. Preston DL, Shimizu Y, Pierce DA, Suyama A, Mabuchi K. Studies of mortality of atomic bomb survivors: report 13-solid cancer and noncancer disease mortality: 1950-1997. Radiat Res. 2003;160:381-407.

2. Doss M, Little MP, Orton CG. Point/counterpoint: low-dose radiation is beneficial, not harmful. Med Phys. 2014;41:070601.

3. Calabrese EJ. The road to linearity: why linearity at low doses became the basis for carcinogen risk assessment. Arch Toxicol. 2009;83:203-225.

4. Lewis EB. Leukemia and ionizing radiation. Science. 1957;125:965-972.

5. National Research Council of the National Academies. Health Risks from Exposure to Low Levels of Ionizing Radiation: BEIR VII Phase 2. Washington, DC: The National Academies Press; 2006:424.

6. Luckey TD. Hormesis with Ionizing Radiation. Boca Raton, FL: CRC Press; 1980:222.

7. Feinendegen LE, Pollycove M, Neumann RD. Hormesis by low dose radiation effects: low-dose cancer risk modeling must recognize up-regulation of protection. In: Baum RP, ed. Therapeutic Nuclear Medicine. Heidelberg: Springer; 2013:789-805.

8. Brody AS, Guillerman RP. Don't let radiation scare trump patient care: 10 ways you can harm your patients by fear of radiation-induced cancer from diagnostic imaging. Thorax. 2014;69:782-784.

9. Sacks B, Meyerson G, Siegel JA. Epidemiology without biology: false paradigms, unfounded assumptions, and specious statistics in radiation science (with commentaries by Inge Schmitz-Feuerhake and Christopher Busby and a reply by the authors). Biol Theory. 2016;11:69-101.

10. Siegel JA, Pennington CW, Sacks B. Subjecting radiologic imaging to the linear no-threshold hypothesis: a non sequitur of non-trivial proportion. J Nucl Med. 2017;58:1-6.

11. Tubiana M. Dose-effect relationship and estimation of the carcinogenic effects of low doses of ionizing radiation: the joint report of the Academie des Sciences (Paris) and of the Academie Nationale de Medecine. Int J Radiat Oncol Biol Phys. 2005;63:317-319.

12. Cardis E, Vrijheid M, Blettner M, et al. Risk of cancer after low doses of ionising radiation: retrospective cohort study in 15 countries. BMJ. 2005;331:77.

13. Ozasa K, Shimizu Y, Suyama A, et al. Studies of the mortality of atomic bomb survivors: report 14, 1950-2003 - an overview of cancer and noncancer diseases. Radiat Res. 2012;177:229-243.

14. Doss M. Linear no-threshold model vs. radiation hormesis. Dose Response. 2013;11:480-497.

15. Zablotska LB, Lane RS, Thompson PA. A reanalysis of cancer mortality in Canadian nuclear workers (1956-1994) based on revised exposure and cohort data. Br J Cancer. 2014;110:214-223.

16. Pearce MS, Salotti JA, Little MP, et al. Radiation exposure from CT scans in childhood and subsequent risk of leukaemia and brain tumours: a retrospective cohort study. Lancet. 2012;380:499-505.

17. Hsieh WH, Lin IF, Ho JC, Chang PW. 30 years follow-up and increased risks of breast cancer and leukaemia after long-term low-dose-rate radiation exposure. $\mathrm{Br}$ J Cancer. 2017;117:1883-1887.
18. Boice JD Jr. Radiation epidemiology and recent paediatric computed tomography studies. Ann ICRP. 2015;44:236-248.

19. Doss M. Comment on ' 30 years follow-up and increased risks of breast cancer and leukaemia after long-term low-dose-rate radiation exposure'. Br J Cancer. 2018;118:e9.

20. Tubiana M, Diallo I, Chavaudra J, et al. A new method of assessing the dosecarcinogenic effect relationship in patients exposed to ionizing radiation: a concise presentation of preliminary data. Health Phys. 2011;100:296-299.

21. Sponsler R, Cameron JR. Nuclear shipyard worker study (1980-1988): a large cohort exposed to low-dose-rate gamma radiation. Int J Low Radiat. 2005;1:463478.

22. NCRP. Commentary No. 27: Implications of Recent Epidemiologic Studies for the Linear-Nonthreshold Model and Radiation Protection. Bethesda, MD: National Council on Radiation Protection and Measurements; 2018:210.

23. Tomasetti C, Li L, Vogelstein B. Stem cell divisions, somatic mutations, cancer etiology, and cancer prevention. Science. 2017;355:1330-1334.

24. DeGregori J. Challenging the axiom: does the occurrence of oncogenic mutations truly limit cancer development with age? Oncogene. 2013;32:1869-1875.

25. White MC, Holman DM, Boehm JE, Peipins LA, Grossman M, Henley SJ. Age and cancer risk: a potentially modifiable relationship. Am J Prev Med. 2014;46 (suppl):S7-S15

26. Teng MW, Swann JB, Koebel CM, Schreiber RD, Smyth MJ. Immune-mediated dormancy: an equilibrium with cancer. J Leukoc Biol. 2008;84:988-993.

27. Risques RA, Kennedy SR. Aging and the rise of somatic cancer-associated mutations in normal tissues. PLoS Genet. 2018;14:e1007108.

28. Greaves M. Does everyone develop covert cancer? Nat Rev Cancer. 2014;14: 209-210.

29. Oliveira Cobucci RN, Saconato H, Lima PH, et al. Comparative incidence of cancer in HIV-AIDS patients and transplant recipients. Cancer Epidemiol. 2012;36:e69-e73.

30. Acuna SA, Fernandes KA, Daly C, et al. Cancer mortality among recipients of solid-organ transplantation in Ontario, Canada. JAMA Oncol. 2016;2:463-469.

31. Biggar RJ, Frisch M, Goedert JJ; AIDS-Cancer Match Registry Study Group. Risk of cancer in children with AIDS. JAMA. 2000;284:205-209.

32. Vandevoorde $\mathrm{C}$, Franck $\mathrm{C}$, Bacher $\mathrm{K}$, et al. gamma-H2AX foci as in vivo effect biomarker in children emphasize the importance to minimize $\mathrm{X}$-ray doses in paediatric CT imaging. Eur Radiol. 2015;25:800-811.

33. Pollycove M, Feinendegen LE. Radiation-induced versus endogenous DNA damage: possible effect of inducible protective responses in mitigating endogenous damage. Hum Exp Toxicol. 2003;22:290-306.

34. Koana T, Tsujimura H. A U-shaped dose-response relationship between x radiation and sex-linked recessive lethal mutation in male germ cells of Drosophila. Radiat Res. 2010;174:46-51.

35. Osipov AN, Buleeva G, Arkhangelskaya E, Klokov D. In vivo gamma-irradiation low dose threshold for suppression of DNA double strand breaks below the spontaneous level in mouse blood and spleen cells. Mutat Res. 2013;756:141145 .

36. Farooque A, Mathur R, Verma A, et al. Low-dose radiation therapy of cancer: role of immune enhancement. Expert Rev Anticancer Ther. 2011;11:791-802.

37. Report of the United Nations Scientific Committee on the Effects of Atomic Radiation. UNSCEAR website. http://www.unscear.org/docs/publications/1958/ UNSCEAR_1958_Report.pdf. Published 1958. Accessed October 4, 2018.

38. Cohen BL. Test of the linear-no threshold theory of radiation carcinogenesis for inhaled radon decay products. Health Phys. 1995;68:157-174.

39. Chaffey JT, Rosenthal DS, Moloney WC, Hellman S. Total body irradiation as treatment for lymphosarcoma. Int J Radiat Oncol Biol Phys. 1976;1:399-405.

40. Sakamoto K. Fundamental and clinical studies on cancer control with total and upper half body irradiation. J JASTRO. 1997;9:161-175.

41. Kostyuchenko VA, Krestinina L. Long-term irradiation effects in the population evacuated from the east-Urals radioactive trace area. Sci Total Environ. 1994;142:119-125.

42. Davis FG, Boice JD Jr, Hrubec Z, Monson RR. Cancer mortality in a radiationexposed cohort of Massachusetts tuberculosis patients. Cancer Res. 1989;49: 6130-6136.

43. Berrington A, Darby SC, Weiss HA, Doll R. 100 years of observation on British radiologists: mortality from cancer and other causes 1897-1997. Br J Radiol. 2001;74:507-519.

44. Evans R. Radium in man. Health Phys. 1974;27:497-510.

45. Grant EJ, Brenner A, Sugiyama H, et al. Solid cancer incidence among the life span study of atomic bomb survivors: 1958-2009. Radiat Res. 2017;187:513537.

46. Richardson DB, Cardis E, Daniels RD, et al. Risk of cancer from occupational exposure to ionising radiation: retrospective cohort study of workers in France, the United Kingdom, and the United States (INWORKS). BMJ. 2015;351:h5359. 
47. Centers for Disease Control and Prevention (CDC). Tobacco use: United States, 1900-1999. MMWR Morb Mortal Wkly Rep. 1999;48:986-993.

48. Graham H. Smoking prevalence among women in the European community 1950-1990. Soc Sci Med. 1996;43:243-254.

49. Taghizadeh N, Vonk JM, Boezen HM. Lifetime smoking history and causespecific mortality in a cohort study with 43 years of follow-up. PLoS One. 2016;11:e0153310

50. Thierry-Chef I, Richardson DB, Daniels RD, et al. Dose estimation for a study of nuclear workers in France, the United Kingdom and the United States of America: methods for the International Nuclear Workers Study (INWORKS). Radiat Res. 2015;183:632-642.

51. Richardson DB, Laurier D, Schubauer-Berigan MK, Tchetgen E, Cole SR. Assessment and indirect adjustment for confounding by smoking in cohort studies using relative hazards models. Am J Epidemiol. 2014;180:933-940.

52. Bruce VR, Belinsky SA, Gott K, et al. Low-dose gamma-radiation inhibits benzo (a)pyrene-induced lung adenoma development in A/J mice. Dose Response. 2012;10:516-526.

53. Little MP, Boice JD Jr. Analysis of breast cancer in the Massachusetts TB fluoroscopy cohort and in the Japanese A-bomb survivors, taking account of dosimetric error and curvature in the A-bomb dose response: absence of evidence of reduction of risk following fractionated irradiation. Int J Low Radiat. 2003;1:88-101.

54. Boice JD Jr, Preston D, Davis FG, Monson RR. Frequent chest X-ray fluoroscopy and breast cancer incidence among tuberculosis patients in Massachusetts. Radiat Res. 1991;125:214-222.

55. Miller AB, Howe GR, Sherman GJ, et al. Mortality from breast cancer after irradiation during fluoroscopic examinations in patients being treated for tuberculosis. N Engl J Med. 1989;321:1285-1289.

56. Howe GR, McLaughlin J. Breast cancer mortality between 1950 and 1987 after exposure to fractionated moderate-dose-rate ionizing radiation in the Canadian fluoroscopy cohort study and a comparison with breast cancer mortality in the atomic bomb survivors study. Radiat Res. 1996;145:694-707.

57. Preston DL, Cullings H, Suyama A, et al. Solid cancer incidence in atomic bomb survivors exposed in utero or as young children. J Natl Cancer Inst. 2008;100:428-436.

58. Lubin JH, Adams MJ, Shore R, et al. Thyroid cancer following childhood lowdose radiation exposure: a pooled analysis of nine cohorts. J Clin Endocrinol Metab. 2017;102:2575-2583.

59. Ahn HS, Kim HJ, Welch HG. Korea's thyroid-cancer "epidemic": screening and overdiagnosis. $N$ Engl J Med. 2014;371:1765-1767.

60. Welch HG, Black WC. Overdiagnosis in cancer. J Natl Cancer Inst. 2010;102: 605-613.

61. Takano T. Natural history of thyroid cancer [review]. Endocr J. 2017;64:237-244.

62. Sokolnikov M, Preston D, Gilbert E, Schonfeld S, Koshurnikova N. Radiation effects on mortality from solid cancers other than lung, liver, and bone cancer in the Mayak worker cohort: 1948-2008. PLoS One. 2015;10:e117784.

63. Brenner AV, Tronko MD, Hatch M, et al. I-131 dose response for incident thyroid cancers in Ukraine related to the Chornobyl accident. Environ Health Perspect. 2011;119:933-939.
64. Eidemüller M, Holmberg E, Jacob P, Lundell M, Karlsson P. Breast cancer risk and possible mechanisms of radiation-induced genomic instability in the Swedish hemangioma cohort after reanalyzed dosimetry. Mutat Res. 2015;775: $1-9$.

65. Eidemüller M, Holmberg E, Jacob P, Lundell M, Karlsson P. Breast cancer risk among Swedish hemangioma patients and possible consequences of radiationinduced genomic instability. Mutat Res. 2009;669:48-55.

66. Brent RL. Carcinogenic risks of prenatal ionizing radiation. Semin Fetal Neonatal Med. 2014;19:203-213.

67. Schonfeld SJ, Krestinina LY, Epifanova S, Degteva MO, Akleyev AV, Preston DL. Solid cancer mortality in the Techa River cohort (1950-2007). Radiat Res. 2013;179:183-189.

68. Wakeford R. Childhood leukaemia following medical diagnostic exposure to ionizing radiation in utero or after birth. Radiat Prot Dosimetry. 2008;132:166-174.

69. Akiba S, Mizuno S. The third analysis of cancer mortality among Japanese nuclear workers, 1991-2002: estimation of excess relative risk per radiation dose. J Radiol Prot. 2012;32:73-83.

70. Kashcheev VV, Chekin SY, Maksioutov MA, et al. Incidence and mortality of solid cancer among emergency workers of the Chernobyl accident: assessment of radiation risks for the follow-up period of 1992-2009. Radiat Environ Biophys. 2015;54:13-23.

71. Liu JJ, Freedman DM, Little MP, et al. Work history and mortality risks in 90,268 US radiological technologists. Occup Environ Med. 2014;71:819-835.

72. Preston DL, Kitahara CM, Freedman DM, et al. Breast cancer risk and protracted low-to-moderate dose occupational radiation exposure in the US Radiologic Technologists Cohort, 1983-2008. Br J Cancer. 2016;115:1105-1112.

73. Boice JD Jr, Cohen SS, Mumma MT, et al. Mortality among mound workers exposed to polonium-210 and other sources of radiation, 1944-1979. Radiat Res. 2014;181:208-228.

74. Boice JD Jr, Cohen SS, Mumma MT, et al. Updated mortality analysis of radiation workers at Rocketdyne (Atomics International), 1948-2008. Radiat Res. 2011;176:244-258.

75. Zhivin S, Guseva Canu I, Samson E, et al. Mortality (1968-2008) in a French cohort of uranium enrichment workers potentially exposed to rapidly soluble uranium compounds. Occup Environ Med. 2016;73:167-174.

76. Sun Z, Inskip PD, Wang J, et al. Solid cancer incidence among Chinese medical diagnostic x-ray workers, 1950-1995: estimation of radiation-related risks. Int J Cancer. 2016;138:2875-2883.

77. Kendall GM, Little MP, Wakeford R, et al. A record-based case-control study of natural background radiation and the incidence of childhood leukaemia and other cancers in Great Britain during 1980-2006. Leukemia. 2013;27:3-9.

78. Amitay EL, Keinan-Boker L. Breastfeeding and childhood leukemia incidence: a meta-analysis and systematic review. JAMA Pediatr. 2015;169: e151025.

79. Rudant J, Lightfoot T, Urayama KY, et al. Childhood acute lymphoblastic leukemia and indicators of early immune stimulation: a childhood leukemia international consortium study. Am J Epidemiol. 2015;181:549-562. 